\section{Quality of Gamma Ray-irradiated Iceberg Lettuce and Treatments to Minimize Irradiation-induced Disorders}

\author{
Xuetong Fan', Kimberly J. Sokorai, and Brendan A. Niemira \\ U.S. Department of Agriculture, Agricultural Research Service, Eastern \\ Regional Research Center, Wyndmoor, PA 19038
}

Robert S. Mills

Tanimura and Antle Fresh Foods, Inc., Salinas, CA 93908

\author{
Mark Yueqian Zhen \\ AgroFresh Inc., Spring House, PA 19477
}

Additional index words. modified atmosphere, 1-methylcyclopropene, packaging, injury, vein browning, nitrogen flushing, russet spotting

\begin{abstract}
Irradiation of Iceberg lettuce was recently approved by the U.S. Food and Drug Administration (FDA) to enhance microbial safety and to extend shelf life at doses up to 4 kGy. However, the radiation tolerance of whole head lettuce is unclear. The present study was conducted to investigate the effects of gamma irradiation on the quality of Iceberg lettuce and explore means to reduce irradiation-induced disorders. Irradiation $(0.5$ and $1.0 \mathrm{kGy}$ ) induced symptoms similar to russet spotting and other discolorations (pink ribs, rusty brown, and vein browning) in both external and internal leaves during postirradiation storage in air at $4{ }^{\circ} \mathrm{C}$. Irradiation in the absence of oxygen or pretreatment with 1 ppm 1-methylcyclopropene had little effect on the irradiation-induced tissue discoloration. However, low oxygen atmosphere when maintained during the entire 14-day storage almost eliminated the disorders. Compared with non-treated control, irradiation created significantly lower headspace $\mathrm{O}_{2}$ and higher $\mathrm{CO}_{2}$ levels in the packages, indicating that irradiation promoted respiration. Our results suggest that modified atmosphere (MA) packaging could be used to mitigate irradiation-induced disorders in Iceberg lettuce.
\end{abstract}

In 2008, ionizing irradiation was approved by the U.S. FDA for use on fresh Iceberg lettuce and spinach at doses not exceeding $4 \mathrm{kGy}$ to enhance microbial safety and to extend shelf life (FDA, 2008). Both whole head lettuce and fresh-cut lettuce are allowed to be treated with radiation. There have been studies on quality of irradiated fresh-cut lettuce (Fan and Sokorai, 2002, 2008, 2011; Fan et al., 2012; Hagenmaier and Baker, 1997) showing that cut lettuce in MA packaging can tolerate up to $1 \mathrm{kGy}$ radiation. Earlier studies on whole head Iceberg lettuce conducted in the 1950s

Received for publication 9 Mar. 2012. Accepted for publication 4 June 2012 .

The study was conducted through a collaborative research agreement with Tanimura and Antle Produce Co. (Agreement No. 58-1935-8-882N).

We thank Dr. John Phillips for advice on statistical analysis and AgroFresh for providing 1-MCP (SmartFresh).

USDA is an equal opportunity employer and provider.

Mention of trade names or commercial products in this article is solely for the purpose of providing specific information and does not imply recommendation or endorsement by the U.S. Department of Agriculture.

${ }^{1}$ To whom reprint requests should be addressed; e-mail xuetong.fan@ars.usda.gov.
Our preliminary results showed that irradiation of whole head lettuce caused injury with a symptom similar to russet spotting, a physiological disorder characterized by the appearance of numerous small brown spots along both sides of the midrib (Ke and Saltveit, 1989). It is known that russet spotting can occur in lettuce that is exposed to ethylene (Ke and Saltveit, 1988), although biotic and abiotic stresses during growth, harvest, and storage can also lead to its development even without exposure to ethylene (Peiser et al., 1998). The development of russet spotting without ethylene exposure is probably the result of endogenous production of stress ethylene. It is also known that irradiation, as a stress, can induce ethylene production in some fruits and vegetables (Abdel-Kader et al., 1968; Hagenmaier and Baker, 1998). Ethylene exerts its effect through binding to its receptors. The ethylene action inhibitor 1-methylcyclopropene (1-MCP) (Sisler and Blankenship, 1996; Sisler and Serek, 1997) blocks ethylene binding to its receptor. Earlier studies (Fan et al., 1999; Fan and Mattheis, 2000) demonstrated that exposing whole Iceberg lettuce to 1-MCP decreased or eliminated tissue discoloration induced by ethylene. However, it is unknown whether 1 -MCP would reduce injury caused by irradiation.

Development of russet spotting and other tissue discolorations generally involves

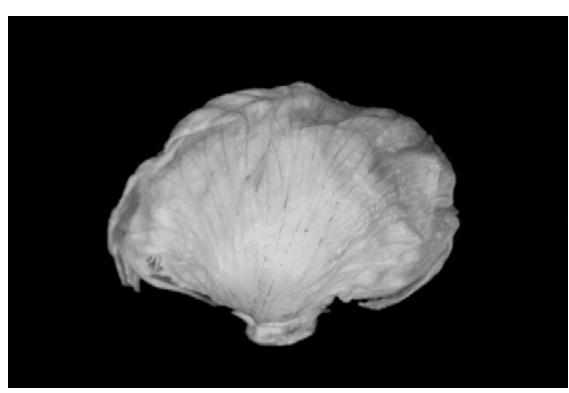

Fig. 1. Typical example of vein browning in

Iceberg lettuce induced by irradiation. and 1960 s showed that doses of 0.5 to $2.0 \mathrm{kGy}$ reduced decay of lettuce but caused severe radiation injury as manifested by spotting, browning, and pink rib, thus precluding the use of irradiation (Bramlage and Lipton, 1965; Thomas, 1988). Kader (1986) put lettuce and leafy vegetables in the category of low tolerance to irradiation.
Table 1. Effect of pretreatment with 1-MCP and nitrogen flushing on external quality of irradiated Iceberg lettuce. ${ }^{\mathrm{z}}$

\begin{tabular}{|c|c|c|c|c|c|c|c|}
\hline \multirow[b]{2}{*}{ Pretreatment } & \multirow{2}{*}{$\begin{array}{c}\text { Storage } \\
\text { time (day) }\end{array}$} & $0 \mathrm{kGy}$ & $0.5 \mathrm{kGy}$ & $1.0 \mathrm{kGy}$ & $0 \mathrm{kGy}$ & $0.5 \mathrm{kGy}$ & $1.0 \mathrm{kGy}$ \\
\hline & & \multicolumn{3}{|c|}{ Hand compression $(1-5)$} & \multicolumn{3}{|c|}{ Overall appearance (9-1) } \\
\hline$\overline{\text { Air }}$ & 1 & $3.5 \pm 0.5 \mathrm{a}$ & $3.1 \pm 0.9 \mathrm{a}$ & $3.3 \pm 0.7 \mathrm{a}$ & $6.8 \pm 0.4 \mathrm{a}$ & $6.8 \pm 0.5 \mathrm{a}$ & $6.8 \pm 0.6 \mathrm{a}$ \\
\hline Air & 7 & $3.4 \pm 0.7 \mathrm{a}$ & $3.4 \pm 0.6 \mathrm{a}$ & $3.0 \pm 0.6 \mathrm{a}$ & $6.5 \pm 1.1 \mathrm{a}$ & $5.2 \pm 0.7 \mathrm{~b}$ & $3.9 \pm 0.9 \mathrm{c}$ \\
\hline ir & 14 & $\pm 0.4 \mathrm{a}$ & $3.7 \pm 0.5 \mathrm{a}$ & $3.1 \pm 0.7 \mathrm{~b}$ & $4 \pm 0.6 \mathrm{a}$ & $5.4 \pm 0.8 \mathrm{~b}$ & $3.6 \pm 1.8 \mathrm{c}$ \\
\hline 1-MCP & 1 & $3.2 \pm 1.0 \mathrm{a}$ & $3.1 \pm 0.7 \mathrm{a}$ & $3.1 \pm 0.9 \mathrm{a}$ & $7.0 \pm 0.4 \mathrm{a}$ & $6.6 \pm 0.4 \mathrm{a}$ & $6.1 \pm 0.9 \mathrm{~b}$ \\
\hline 1-MCP & 7 & $2 \pm 0.8 \mathrm{a}$ & $3.1 \pm 0.7 \mathrm{a}$ & $3.3 \pm 0.3 \mathrm{a}$ & $5.7 \pm 1.1 \mathrm{a}$ & $4.3 \pm 1.7 b$ & $4.1 \pm 0.7 b$ \\
\hline 1-MCP & 14 & $4 \pm 0.4 b$ & $3.7 \pm 0.8 \mathrm{a}$ & $3.3 \pm 0.6 \mathrm{ab}$ & $5.3 \pm 1.8 \mathrm{a}$ & $4.9 \pm 1.2 \mathrm{ab}$ & $4.3 \pm 1.2 \mathrm{~b}$ \\
\hline $\mathrm{N}_{2}$ flushing & 1 & $3 \pm 0.9 \mathrm{a}$ & $3.8 \pm 0.6 \mathrm{a}$ & $3.6 \pm 0.6 \mathrm{a}$ & $6.8 \pm 0.6 \mathrm{a}$ & $6.5 \pm 0.5 \mathrm{a}$ & $6.9 \pm 0.7 \mathrm{a}$ \\
\hline$I_{2}$ flushing & 7 & $7 \pm 0.6 \mathrm{a}$ & $3.5 \pm 1.1 \mathrm{a}$ & $3.4 \pm 0.8 \mathrm{a}$ & $5.9 \pm 1.3 \mathrm{a}$ & $4.9 \pm 0.9 \mathrm{~b}$ & $5.3 \pm 0.9 a$ \\
\hline $\mathrm{N}_{2}$ flushing & 14 & $3.2 \pm 0.6 \mathrm{a}$ & $3.3 \pm 0.8 \mathrm{a}$ & $2.9 \pm 0.6 \mathrm{a}$ & $5.1 \pm 2.2 \mathrm{a}$ & $5.1 \pm 1.5 \mathrm{a}$ & $4.3 \pm 1.2 \mathrm{a}$ \\
\hline $\operatorname{LsDD}_{0.05}$ & & 0.4 & 0.5 & 0.4 & 0.7 & 0.6 & 0.6 \\
\hline Pretreatment & & NS & NS & NS & $* *$ & $*$ & $* * *$ \\
\hline Storage & & NS & NS & NS & $* * *$ & $* * *$ & $* * *$ \\
\hline Pretreatment & $\times$ storage & NS & * & NS & $*$ & NS & $* * *$ \\
\hline
\end{tabular}

${ }^{\mathrm{z}}$ After irradiation at $0,0.5$ and $1.0 \mathrm{kGy}$, the lettuce was stored in air (perforated film bags) at $4{ }^{\circ} \mathrm{C}$ for $14 \mathrm{~d}$. The numbers are means followed by SDs. Means with same letters within same row are not significantly different $(P<0.05)$. Ns, $* * *$, and $* * *$ represent nonsignificant, significant at $0.05,0.01$, and 0.001 levels, respectively, for each treatment or interaction between treatments.

$\mathrm{LSD}_{0.05}$ represents significant difference at 0.05 level.

1 -MCP = 1-methylcyclopropene; LSD = least significant difference. 


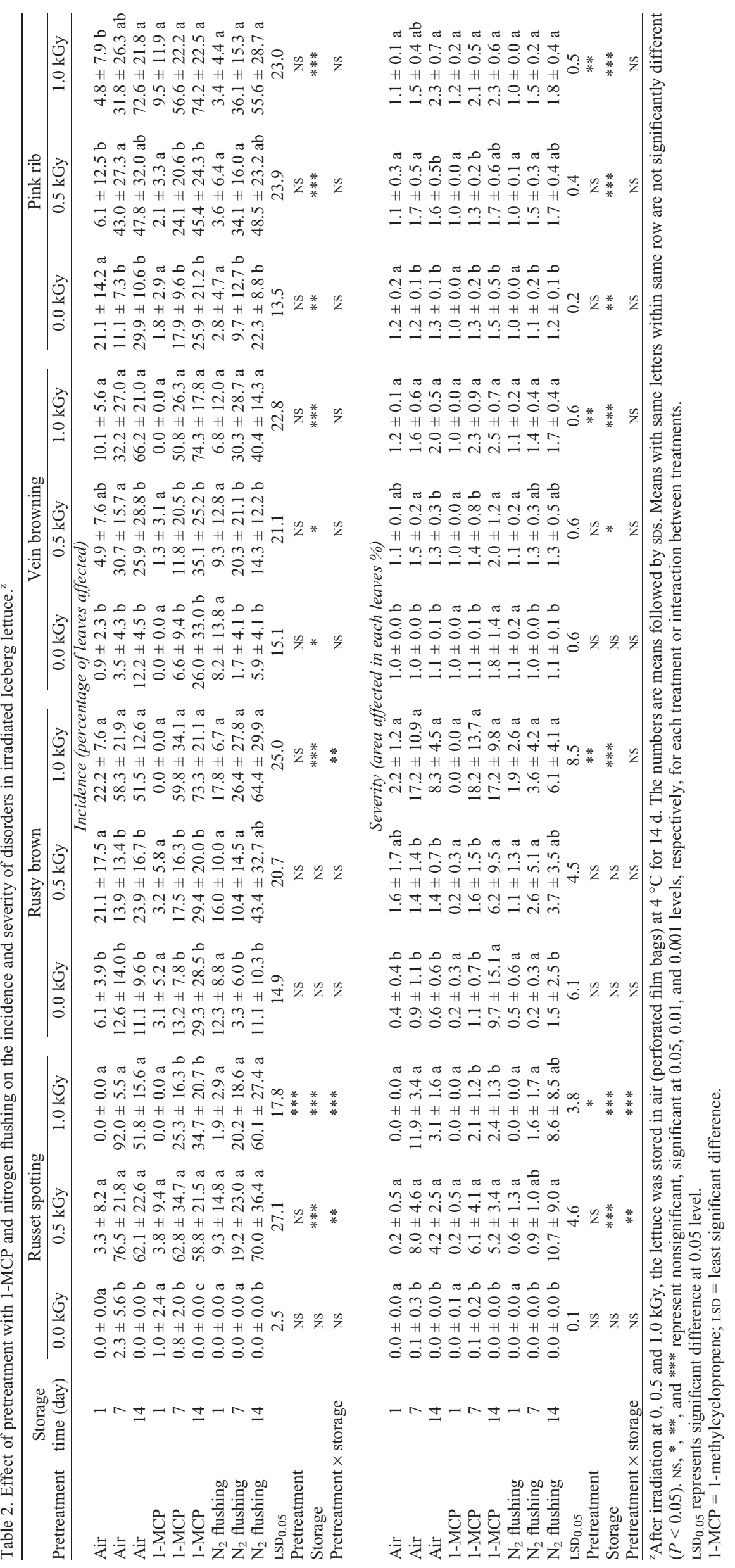

accumulation and oxidation of phenolic compounds catalyzed by polyphenol oxidase (PPO), peroxidase (POD), and other enzymes such as phenylalanine ammonia-lyase (PAL) and indole-3-acetic acid oxidase (IAA). It is known that ethylene induces PAL and POD activities and increases the synthesis of phenolic compounds, which are converted to brown pigments by the action of PPO (Ke and Saltveit, 1988). Low oxygen and high $\mathrm{CO}_{2}$ can inhibit ethylene action (Burg and Burg, 1969), and the inhibition of ethylene action prevents the induction of PAL and IAA oxidase and inhibits activities of PPO and POD, thus inhibiting tissue discoloration (Ke and Saltveit, 1988, 1989). Indeed, low oxygen $(0.5 \%$ to $8 \%)$ effectively reduced development of russet spotting (Lipton, 1967; Zagory and Kader, 1988). Our earlier study (Fan and Sokorai, 2011) on cut Iceberg lettuce showed that irradiation induced tissue browning, and MA packaging (MAP) reduced the development of tissue browning. However, it is unknown whether low oxygen and/high $\mathrm{CO}_{2}$ would reduce irradiation-induced injury in whole head lettuce. The disorders developed on whole Iceberg lettuce were different from those on cut lettuce.

In our preliminary study, whole head lettuce was irradiated at 0.5 and $1.0 \mathrm{kGy}$. After 7 and 14 $\mathrm{d}$ of storage in air at $4{ }^{\circ} \mathrm{C}$, irradiated lettuce had lower scores of overall appearance than the non-irradiated samples. In addition, individual leaves of heat lettuce also developed russet spotting, rusty brown, vein browning (vein stain; Fig. 1) and pink rib. The present study focused on the effects of 1-MCP, nitrogen flushing, and MAP on irradiation-induced injury.

\section{Materials and Methods}

Source of lettuce. The experiments were conducted over a 6-month period. Iceberg lettuce was provided by a major California lettuce grower. Whole head lettuce was filmwrapped and carton-packed in the field, vacuum-cooled, and stored at 1 to $4{ }^{\circ} \mathrm{C}$ for less than $24 \mathrm{~h}$ before being shipped from California or Arizona to the Philadelphia Distribution Center in refrigeration trucks, which generally took 3 to $5 \mathrm{~d}$. On receipt, the lettuce was transferred to the USDA, Eastern Regional Research Center and stored overnight at $4{ }^{\circ} \mathrm{C}$ before being treated.

Pretreatment with 1-methylcyclopropene and $\mathrm{N}_{2}$ flushing. 1-MCP (SmartFresh ${ }^{\mathrm{TM}}$ ) was kindly provided by AgroFresh Inc. (Spring House, PA). For the 1-MCP treatment, whole head lettuce was placed into 34-gallon plastic containers at $4{ }^{\circ} \mathrm{C}$. The containers were sealed with lids and tape. There were nine heads of lettuce in each container and there were three containers (three replicates) for the 1-MCP treatments. 1-MCP generated outside of the containers was pumped through the containers through two outlets. The amount of SmartFresh powder was calculated according to the manufacturer's suggestion so that $1.5 \mathrm{ppm} 1-\mathrm{MCP}$ was achieved in the containers. Actual 1-MCP concentrations were confirmed using a gas chromatograph at the beginning and end of treatments. Treatment time was $\approx 16 \mathrm{~h}$. 1-MCP was measured using a HP 6890 GC (Agilent 
Technologies, Foster City, CA) equipped with a flame ionization detector and a CP7350 column (Varian Inc., Palo Alto, CA) (Fan et al., 1999). The $\mathrm{O}_{2}$ and $\mathrm{CO}_{2}$ levels in the containers were also monitored using an oxygen/carbon dioxide analyzer (Model 902D; Quantek Instruments, Grafton, MA). The $\mathrm{O}_{2}$ levels decreased to $18 \%$, whereas $\mathrm{CO}_{2}$ increased to $2 \%$ after overnight treatment. Non-treated samples were sealed in similar containers overnight.

For $\mathrm{N}_{2}$ flushing, whole head lettuce was placed in $28 \times 34-\mathrm{cm}$ aluminized polypropylene barrier (foil) bags (FR-2175-B; Covalence Coated Products, Columbus, GA), vacuumed to 200 mbar, evacuated for $2 \mathrm{~s}$, flushed with nitrogen to $700 \mathrm{mbar}$, and sealed for $3 \mathrm{~s}$ using a Multivac C-450 Vacuum Packager (Kansas City, MO). Levels of $\mathrm{O}_{2}$ and $\mathrm{CO}_{2}$ were measured (through a septum in the bag) after flushing and sealing and before and after irradiation. The lettuce in sealed foil bags was stored at $4{ }^{\circ} \mathrm{C}$ overnight before being irradiated to $0,0.5$, and $1.0 \mathrm{kGy}$ radiation along with the samples pretreated with 1-MCP. Irradiation and dosimetry were performed using a selfcontained gamma radiation source (Lockheed Georgia Company, Marietta, GA) as described earlier (Fan and Sokorai, 2002; Shieh et al., 1985). After irradiation, lettuce pretreated with 1-MCP or $\mathrm{N}_{2}$ flushing was stored in air (perforated film bags) for $14 \mathrm{~d}$. External and internal quality of head lettuce and disorders of each leaf were assessed at 1, 7, and $14 \mathrm{~d}$.

Modified atmosphere packaging storage. Whole head lettuce was either in its original perforated wrap or put in $12 \times 18$-inch PD961EZ film bags (Cryovac, Duncan, SC; oxygen transmission rate: 6000 to $8000 \mathrm{~mL} /$ $\mathrm{m}^{2} / 24 \mathrm{~h}$ ) after removal of the perforated wraps. The film bags were evacuated and then filled with nitrogen before being sealed using the Multivac Vacuum Packager with the same setting as described in previous paragraph. The samples (in perforated wraps and in MAP) were then irradiated to $0,0.5$ and 1.0 $\mathrm{kGy}$ gamma rays. After irradiation, the samples were stored either in air (perforated film bags) or MAP at $4{ }^{\circ} \mathrm{C}$ for $14 \mathrm{~d}$. Gas composition in the film bags was measured immediately after sealing and after 1, 7, and $14 \mathrm{~d}$ of storage.

Quality assessment. Overall external appearance was assessed using a scale developed previously (Kader et al., 1973) by three to four judges. The assessment of the appearance by the judges was facilitated using color charts (Kader and Cantwell, 2008) and training sessions on real samples. The judges were trained twice with duration of $0.5 \mathrm{~h}$ each session to be familiar with common lettuce disorders and the scale of ratings. The ratings for appearance were: 1 represents heads that are not usable, 3 represents heads that have excessive defects, 5 represents heads that have moderate defects and are the lower limit of sales appeal, 7 represents heads that have minor defects, and 9 represents heads that are essentially free from defects. The visual quality encompassed defects such as decay, external discoloration (russet spotting, pink rib, etc.), and wilting. Firmness of whole head lettuce was assessed using a hand compression test by placing a head of lettuce between two palms and applying pressure. The scale for firmness was rated in a scale of 1 to 5 (Kader et al., 1973) where a rating of 1 represents heads that are soft and easily compressed, 3 represents heads that are firm and may yield slightly to moderate pressure, and 5 represents heads that are extrahard and may have cracked ribs when compressed.

After external quality assessment, individual leaves of each head of lettuce were peeled and visually evaluated by the same panelists for russet spotting, rusty brown, vein browning, and pink rib. There were 17 to 25 leaves in each head of lettuce. The number of disorders as well as area of leaves affected by each disorder was estimated for each leaf, which resulted in two sets of data for the disorders: the number of leaves with disorders in each head and average distribution of disorders per leaf, which represented the incidence and severity of the disorders, respectively.

Experimental design and statistical analysis. The experimental design was a completely randomized design of radiation doses, storage times, and/or pretreatment as main factors. Two independent trials were performed for each of the experiments with four heads of lettuce each treatment each trial (except for 1-MCP study). The data from the two trials were combined to give eight replicates. The experiment on the 1-MCP effect was only run once with three heads of lettuce each treatment. Data were analyzed with SAS Version 8 (SAS Institute, Cary, NC). Effects of storage time, radiation dose, MAP, and pretreatments with 1-MCP and nitrogen flushing were analyzed using the least significant difference test of the General Linear Model procedure.

\section{Results and Discussion}

Effect of pretreatment with 1-methylcyclopropene and nitrogen flushing. Concentrations of 1-MCP in the containers were $1.3 \pm$ 0.2 and $0.8 \pm 0.1 \mathrm{ppm}$ at the beginning and end of 1-MCP treatments, respectively. The $\mathrm{O}_{2}$ and $\mathrm{CO}_{2}$ levels in the foil bags were $1.9 \pm 0.6$ and $0.9 \pm 0.2 \%$, respectively, immediately after sealing and were $0.2 \% \pm 0.2 \%$ and $3.0 \% \pm$ $0.7 \%$, respectively, measured immediately after irradiation.

Firmness of lettuce was generally unaffected by irradiation or by pretreatment with $1-\mathrm{MCP}$ or nitrogen flushing except that lettuce treated with $1 \mathrm{kGy}$ radiation in air had lower firmness, and samples that were pretreated with 1-MCP and received $0.5 \mathrm{kGy}$ irradiation had higher firmness than corresponding samples at Day 14 (Table 1). The results suggested that there were large variations in firmness of whole lettuce and the firmness was not consistently affected by the low-dose irradiation. Earlier studies (Fan and Sokorai, 2002, 2011) showed that irradiation at doses up to $1 \mathrm{kGy}$ did not significantly affect firmness of cut lettuce although irradiation induced softening of some other fruits and vegetables (Fan, 2012; Prakash et al., 2000).

Similar to our preliminary results, the external appearance of irradiated lettuce in air was worse than that of non-irradiated samples at Days 7 and 14 (Table 1). Pretreatment with $1-\mathrm{MCP}$ and nitrogen flushing during irradiation

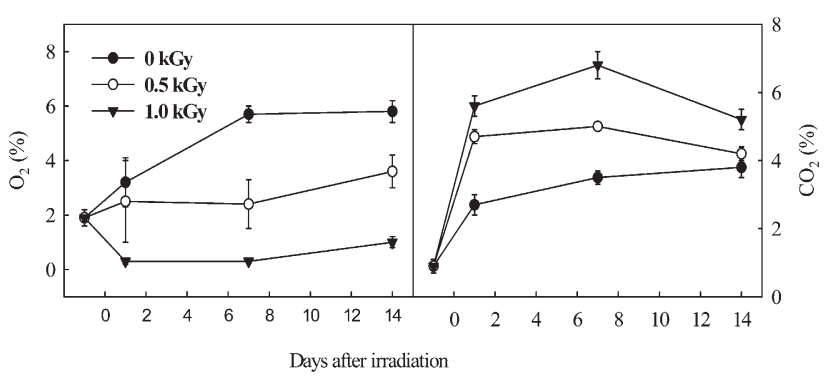

Fig. 2. Change in headspace composition in modified atmosphere package (MAP) of Iceberg lettuce during storage at $4{ }^{\circ} \mathrm{C}$. Vertical bars represent SEs $(n=8)$.

Table 3. External quality of Iceberg lettuce after irradiation during storage in air (perforated film bags) or modified atmosphere package at $4{ }^{\circ} \mathrm{C}$.

\begin{tabular}{|c|c|c|c|c|c|c|c|}
\hline \multirow[b]{2}{*}{ Package } & \multirow{2}{*}{$\begin{array}{c}\text { Storage } \\
\text { time (day) }\end{array}$} & 0 kGy & $0.5 \mathrm{kGy}$ & $1.0 \mathrm{kGy}$ & 0 kGy & $0.5 \mathrm{kGy}$ & $1.0 \mathrm{kGy}$ \\
\hline & & \multicolumn{3}{|c|}{ Hand compression $(1-5)$} & \multicolumn{3}{|c|}{ Overall appearance $(9-1)$} \\
\hline$\overline{\text { Air }}$ & 1 & $3.6 \pm 0.7 \mathrm{ab}$ & $3.9 \pm 0.7 \mathrm{a}$ & $3.1 \pm 1.0 \mathrm{~b}$ & $6.9 \pm 0.7 \mathrm{a}$ & $6.9 \pm 0.7 \mathrm{a}$ & $6.8 \pm 0.8 \mathrm{a}$ \\
\hline Air & 7 & $3.1 \pm 1.0 \mathrm{ab}$ & $3.5 \pm 0.6 \mathrm{a}$ & $2.8 \pm 0.6 b$ & $6.7 \pm 0.7 \mathrm{a}$ & $5.0 \pm 0.9 b$ & $4.5 \pm 1.3 b$ \\
\hline Air & 14 & $3.3 \pm 1.0 \mathrm{a}$ & $3.4 \pm 0.5 \mathrm{a}$ & $3.6 \pm 0.5 \mathrm{a}$ & $6.0 \pm 1.9 \mathrm{a}$ & $5.0 \pm 1.1 \mathrm{~b}$ & $4.6 \pm 1.0$ \\
\hline MAP & 1 & $3.7 \pm 0.7 \mathrm{a}$ & $3.9 \pm 0.9 \mathrm{a}$ & $2.9 \pm 0.9 \mathrm{~b}$ & $7.2 \pm 0.6 \mathrm{a}$ & $7.2 \pm 0.4 \mathrm{a}$ & $7.5 \pm 0.6 \mathrm{a}$ \\
\hline MAP & 7 & $3.4 \pm 0.6 \mathrm{a}$ & $3.4 \pm 0.8 \mathrm{a}$ & $3.0 \pm 0.8 \mathrm{a}$ & $6.9 \pm 1.0 \mathrm{a}$ & $6.8 \pm 0.9 \mathrm{a}$ & $7.0 \pm 0.7$ \\
\hline MAP & 14 & $3.5 \pm 0.5 \mathrm{a}$ & $3.3 \pm 0.7 \mathrm{a}$ & $3.1 \pm 0.7 \mathrm{a}$ & $6.5 \pm 0.7 \mathrm{a}$ & $6.2 \pm 1.2 \mathrm{a}$ & $6.4 \pm 0.9$ \\
\hline \multicolumn{2}{|l|}{$\operatorname{LSD}_{0.05}$} & 0.5 & 0.4 & 0.5 & 0.6 & 0.5 & 0.5 \\
\hline \multicolumn{2}{|l|}{ Package } & NS & NS & NS & $*$ & $* * *$ & $* * *$ \\
\hline \multirow{2}{*}{\multicolumn{2}{|c|}{ Storage }} & NS & $* *$ & $*$ & $* * *$ & $* * *$ & $* * *$ \\
\hline & & NS & NS & NS & NS & $* *$ & $* * *$ \\
\hline
\end{tabular}

The numbers are means followed by SDs. Means with same letters within same row are not significantly different $(P<0.05)$. Ns, ${ }^{*}, * *$, and $* * *$ represent non-significant, significant at $0.05,0.01$, and 0.001 levels, respectively, for each treatment or interaction between treatments.

$\mathrm{LSD}_{0.05}$ represents significant difference at 0.05 level.

$\mathrm{MAP}=$ modified atmosphere packaging; LSD = least significant difference. 


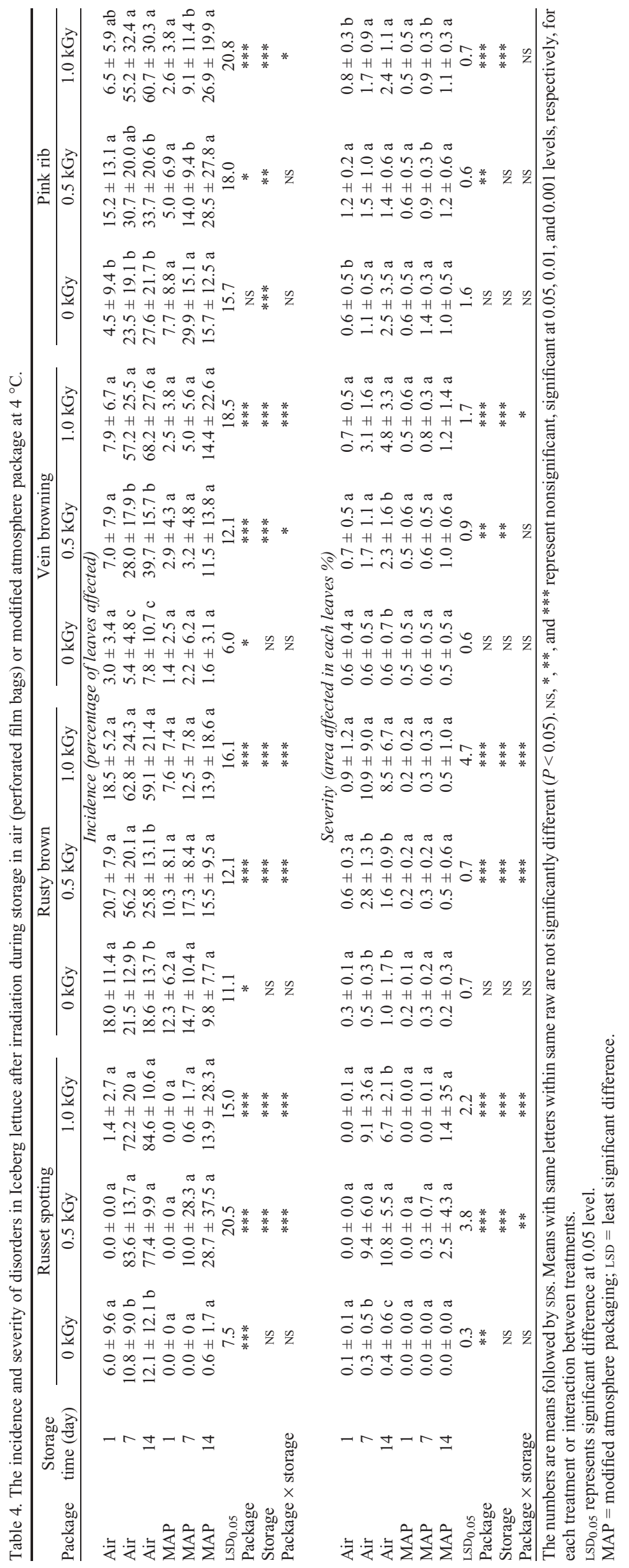

generally did not have any significant effect on the irradiation-induced disorders, because irradiated samples had lower scores of overall appearance than corresponding non-irradiated ones regardless of pretreatments.

The percentages of leaves with russet spotting as well as the area affected by russet spotting in lettuce that received irradiation in air were significantly higher than those for the non-irradiated ones (Table 2). In 1-MCP-pretreated lettuce, russet spotting was still much higher for irradiated samples than for the nonirradiated ones. Similarly, nitrogen flushing before irradiation had little effect on the radiation-induced russet spotting. The rusty brown discoloration was promoted by $1 \mathrm{kGy}$ irradiation in air samples. Pretreatment with 1-MCP or nitrogen flushing had no significant effect on the radiation-induced rusty brown.

The incidence (percentage of leaves affected in each head) and severity (percentage of area affected in each leave) of vein browning were increased by irradiation in the air samples Pretreatment with 1-MCP or nitrogen flushing did not reduce the occurrence of vein browning induced by irradiation. The pink rib induced by irradiation was not reduced by pretreatments with 1-MCP or nitrogen flushing either. There were large variations in the results of incidence and severity of the disorders, probably as a result of variations in lettuce because the experiments were conducted over a 6-month period. Increasing the number of lettuce samples may reduce the variations. In addition, increasing the number of judges and training sessions for the evaluation of the disorders may further minimize experimental errors and reduce the variations in the ratings.

Overall, our results showed that pretreatment with 1-MCP did not have a substantial effect on irradiation-induced development of the disorders. Therefore, it appears that irradiation-induced development of russet spotting and other disorders is independent of ethylene action. Our earlier results (Fan and Mattheis, 2001) on apples showed that irradiation-induced fruit softening was unaffected by the inhibition of ethylene action. Pretreatment of endive with 1-MCP did not reduce red discoloration of cut endive (Salman et al., 2009).

Our results also showed that pretreatment with nitrogen flushing, which resulted in the exclusion of oxygen during irradiation, did not significantly reduce the development of discoloration caused by irradiation (Tables 1 and 2). Development of discolorations such as russet spotting generally involves accumulation and oxidation of phenolic compounds catalyzed by PPO and POD. Although pretreatment with nitrogen flushing oxygen should eliminate or reduce development of discoloration because low oxygen inhibits activities of many enzymes, oxygen was only excluded during the period of irradiation. Therefore, oxygen exclusion needs to be extended to post-irradiation storage.

Effect of modified atmosphere packaging. The $\mathrm{O}_{2}$ and $\mathrm{CO}_{2}$ levels in the MA packages were $1.9 \% \pm 0.6 \%$ and $0.9 \% \pm 0.2 \%$, respectively, just after packaging and flushing 
with nitrogen (Fig. 2). One day after irradiation, packages of irradiated lettuce had significantly lower $\mathrm{O}_{2}$ and higher $\mathrm{CO}_{2}$ levels than the non-irradiated ones. Although both $\mathrm{O}_{2}$ and $\mathrm{CO}_{2}$ levels increased in all samples (with $\mathrm{O}_{2}$ in the 1-kGy sample increased at a slower rate) during storage, lower $\mathrm{O}_{2}$ and higher $\mathrm{CO}_{2}$ levels were always observed in irradiated samples in comparison with the non-irradiated ones. The slower rate of increase in the $\mathrm{O}_{2}$ level in the 1-kGy sample suggested that the 1-kGy sample consumed more $\mathrm{O}_{2}$ than other samples. The $\mathrm{O}_{2}$ levels were $3.2 \%$ to $5.8 \%$, $2.5 \%$ to $3.6 \%$, and $0.3 \%$ to $1.0 \%$, whereas the $\mathrm{CO}_{2}$ levels were $2.7 \%$ to $3.8 \%, 4.7 \%$ to $5.0 \%$, and $5.2 \%$ to $6.8 \%$ for the $0,0.5$, and $1.0 \mathrm{kGy}$, respectively. Our results indicated that radiation increased respiration of lettuce although we did not measure respiration directly. Earlier studies have demonstrated the effect of irradiation on respiration of fresh-cut Iceberg lettuce (Hagenmaier and Baker, 1997) and other lettuce. However, Prakash et al. (2000) found low-dose irradiation reduced respiration rate of 'Romaine' lettuce.

Firmness of MAP lettuce was not consistently affected by irradiation (Table 3 ). The only significant effect was that firmness of lettuce irradiated at $1 \mathrm{kGy}$ in MAP was lower than the corresponding ones at Day 1. Irradiation had no effect on overall appearance $1 \mathrm{~d}$ after irradiation regardless of MAP (Table 3 ). However, external appearance scores of lettuce irradiated in air were 5 (the lower limit of sales appeal) or lower after 7 and $14 \mathrm{~d}$ of storage. When the lettuce were irradiated and stored in the MAP, the overall appearance of irradiated lettuce was similar to those of non-irradiated ones with scores of 6.2 to 7.0.

One day after irradiation, irradiation had no significant effect on the incidence and severity of russet spotting, rusty brown, vein browning, or pink rib (Table 4). Both incidence and severity of russet spotting of each leaf was increased by 0.5 and $1.0 \mathrm{kGy}$ irradiation after 7 and $14 \mathrm{~d}$ of storage. When the lettuce was packaged in MAP, irradiation did not induce a significant increase in russet spotting, indicating that MAP eliminated the formation of russet spotting. Similarly, formation of rusty brown, vein browning, and pink rib was also eliminated or significantly reduced by the use of MAP during irradiation and storage. MAP was also effective in eliminating or significantly reducing the discolorations when MAP was applied within $2 \mathrm{~h}$ after irradiation (data not shown). Therefore, it appears that irradiated-induced disorders initiated after irradiation. When MAP was removed after $7 \mathrm{~d}$ of storage, irradiationinduced discolorations occurred during subsequent air storage, but the severity of the disorders was much less compared with those stored in air all the time (data not shown).

There have been a number of studies regarding the effect of MAP on irradiated cut lettuce. For example, Massey et al. (2006) found that irradiation increased $\mathrm{O}_{2}$ consumption and $\mathrm{CO}_{2}$ production of lettuce. Fan and Sokorai $(2002,2011)$ found that fresh-cut Iceberg lettuce packed in MAP and irradiated at $1 \mathrm{kGy}$ had less tissue browning and better overall visual appearance compared with the non-irradiated one. In addition, the better quality was related to high $\mathrm{CO}_{2}$ and low $\mathrm{O}_{2}$ levels observed in packages of the irradiated samples. Foley et al. (2002) found that irradiation $(0.55 \mathrm{kGy})$ did not cause any change in texture or other sensory attributes of fresh-cut lettuce when packaged in film bags. In the present study, we demonstrated that irradiation induced development of several disorders unique to whole lettuce, and use of MAP reduced the occurrence of the disorders.

Our results demonstrated that gamma irradiation at doses of 0.5 and $1.0 \mathrm{kGy}$ induced several types of disorders (discolorations) of Iceberg lettuce, occurring during postirradiation storage, with characteristics similar to russet spotting, pink ribs, and rusty brown. In addition, irradiation also induced browning of veins. Pretreatment with 1-MCP, an ethylene action inhibitor, did not have a significant effect on the development of these disorders. Furthermore, elimination of oxygen during irradiation did not reduce the development of discoloration. However, packaging Iceberg lettuce in MA before irradiation and during storage eliminated most of the discolorations. Therefore, our results indicate that MA packaging can be used to minimize the injury caused by irradiation on Iceberg lettuce.

\section{Literature Cited}

Abdel-Kader, A.S., L.L. Morris, and E.C. Maxie. 1968. Physiology studies of gamma irradiated tomato fruits: I. Effect on respiratory rate, ethylene production, and ripening. Proc. Amer. Soc. Hort. Sci. 92:553-567.

Bramlage, W.J. and W.J. Lipton. 1965. Gamma radiation of vegetables to extend market life. Marketing Research Report. No. 703. Agricultural Research Service. U.S. Department of Agriculture, Washington, DC.

Burg, S.P. and E.A. Burg. 1969. Interaction of ethylene, oxygen, and carbon dioxide in the control of fruit ripening. Qual. Plant Matter Veg. 19:185-200.

Fan, X. 2012. Ionizing radiation, p. 379-406. In: Gómez-López, V. (ed.). Decontamination of fresh and minimally processed produce. WileyBlackwell, West Sussex, UK.

Fan, X., S.M. Blankenship, and J.P. Mattheis. 1999. 1-Methylcyclopropene inhibits apple fruit ripening. J. Amer. Soc. Hort. Sci. 124: 690-695.

Fan, X., W. Guan, and K.J.B. Sokorai. 2012. Quality of fresh-cut Iceberg lettuce and spinach irradiated at doses up to $4 \mathrm{kGy}$. Radiat. Phys. Chem. 81:1071-1075.

Fan, X. and J.P. Mattheis. 2000. Reduction of ethylene-induced physiological disorders of carrots and Iceberg lettuce by 1-methylcyclopropene. HortScience 35:1312-1314.

Fan, X. and J.P. Mattheis. 2001. 1-methylcyclopropene and storage temperature influence responses of 'Gala' apple fruit to gamma irradiation. Postharvest Biol. Technol. 23:143-151.

Fan, X. and K.J.B. Sokorai. 2002. Sensorial and chemical quality of gamma irradiated fresh-cut iceberg lettuce in modified atmosphere packages. J. Food Prot. 65:1760-1765.

Fan, X. and K.J.B. Sokorai. 2008. Retention of quality and nutritional value of thirteen freshcut vegetables treated with low dose radiation. J. Food Sci. 73:S367-S372.
Fan, X. and K.J.B. Sokorai. 2011. Effects of gamma irradiation, modified atmosphere packaging and delay of irradiation on quality of fresh-cut Iceberg lettuce. HortScience 46:273-277.

FDA. 2008. Irradiation in the production, processing and handling of food. Fed. Regist. 73:4959349603.

Foley, D.M., A. Dufour, L. Rodriguez, F. Caporaso, and A. Prakash. 2002. Reduction of Escherichia coli 0157:H7 in shredded Iceberg lettuce by chlorination and gamma irradiation. Radia. Phys. Chem. 63:391-396.

Hagenmaier, R.D. and A. Baker. 1997. Low-dose irradiation of cut Iceberg lettuce in modified atmosphere packaging. J. Agr. Food Chem. 45: 2864-2868.

Hagenmaier, R.D. and R.A. Baker. 1998. Microbial population of shredded carrot in modified atmosphere packaging as related to irradiation treatment. J. Food Sci. 63:162-164.

Kader, A.A. 1986. Potential applications of ionizing radiation in postharvest handling of fresh fruits and vegetables. Food Technol. 40:117-121.

Kader, A.A. and M. Cantwell. 2008. Produce quality rating scales and color charts. Postharvest Technology Research and Information Center, University of California, Davis, CA.

Kader, A.A., W.J. Lipton, and L.L. Morris. 1973. Systems for scoring quality of harvested lettuce. HortScience 8:408-409.

Ke, D. and M.E. Saltveit. 1988. Plant hormone interaction and phenolic metabolism in the regulation of russet spotting in Iceberg lettuce. Plant Physiol. 88:1136-1140.

Ke, D. and M.E. Saltveit. 1989. Regulation of russet spotting, phenolic, metabolism and IAA oxidase by low oxygen in Iceberg lettuce. J. Amer. Soc. Hort. Sci. 114:638-642.

Lipton, W.J. 1967. Market quality and rate of respiration of head lettuce held in low-oxygen atmospheres. USDA/ARS Mktg. Res. Rpt. 777.

Massey, L.M., Jr., D.F. Tallman, and Z.I. Kertesz. 2006. Effects of ionizing radiations on plant tissues. V. Some effects of gamma radiation on lettuce leaves. J. Food Sci. 26:389-396.

Peiser, G., G. López-Gálvez, M. Cantwell, and M.E. Saltveit. 1998. Phenylalanine ammonialyase inhibitors do not prevent russet spotting lesion development in lettuce midribs. J. Amer. Soc. Hort. Sci. 123:687-691.

Prakash, A., A.R. Guner, F. Caporaso, and D.M. Foley. 2000. Effects of low-dose gamma irradiation on the shelf life and quality characteristics of cut Romaine lettuce packaged under modified atmosphere. J. Food Sci. 65:549-554.

Salman, A., H. Filgueiras, S. Cristescu, F. LopezLauri, F. Harren, and H. Sallanon. 2009. Inhibition of wound-induced ethylene does not prevent red discoloration in fresh-cut endive (Cichorium intybus L.). Eur. Food Res. Technol. 228:651-657.

Shieh, J.J., R.K. Jenins, and E. Wierbicki. 1985. Dosimetry and dose distribution in cesium-137 irradiation unit used at the Eastern Regional Research Center. Radia. Phys. Chem. 25:779-792.

Sisler, E.C. and S.M. Blankenship. 1996. Method of counteracting an ethylene response in plants. US Patent No. 5,518,988

Sisler, E.C. and M. Serek. 1997. Inhibitors of ethylene responses in plants at the receptor level: Recent developments. Physiol. Plant. 100:577-582.

Thomas, P. 1988. Radiation preservation of foods of plant origin. Part VI. Mushrooms, tomatoes, minor fruits and vegetables, dried fruits and nuts. CRC Crit. Rev. Food Sci. Nutr. 26:313-358.

Zagory, D. and A.A. Kader. 1988. Modified atmosphere packaging of fresh produce. Food Technol. 42:70-74, 76-77. 